\title{
Pengaruh Likuiditas, Leverage, Kebijakan Dividen, Ukuran Perusahaan, Good Corporate Governance dan Sales Growth Terhadap Nilai Perusahaan
}

\author{
Nita Putri Herdiani ${ }^{1}$, Tenny Badina ${ }^{2}$, Rita Rosiana ${ }^{3}$ \\ 1Jurusan Ekonomi Syariah, Universitas Sultan Ageng Tirtayasa \\ Email: herdianiputrinita@gmail.com \\ 2Jurusan Ekonomi Syariah, Universitas Sultan Ageng Tirtayasa \\ Email: tennybadina@gmail.com \\ 3 3urusan Ekonomi Syariah, Universitas Sultan Ageng Tirtayasa \\ Email: rosiana rita@untirta.ac.id
}

\begin{abstract}
This study was conducted to determine the effect of liquidity, leverage, dividend policy, firm size, good corporate governance, and sales growth on firm value in manufacturing companies listed on the Indonesian Sharia Stock Index (ISSI) for the 2016 - 2020 period. Listed on the Indonesian Sharia Stock Index (ISSI) with a study period of 5 years. The sample selection method was purposive sampling and obtained 29 companies that matched the sample criteria. The data analysis method uses panel data and ordinary least square (OLS). The results of hypothesis testing show that partially liquidity has a negative and significant effect on firm value, leverage has a negative and significant effect on firm value, dividend policy has a positive and significant effect on firm value, firm size has a positive and significant effect on firm value, board of commissioners size has a negative and significant effect on firm value, audit committee size has a negative and significant effect on firm value, and sales growth has a negative and significant effect on firm value. Simultaneously there is a significant influence of liquidity, leverage, dividend policy, firm size, board of commissioners size, audit committee size, and sales growth on firm value.
\end{abstract}

Keywords: Firm Value, Liquidity, Leverage, Dividend Policy, Firm Size, Board of Commissioners Size, Audit Committee Size, Sales Growth.

ABSTRAK
Penelitian ini dilakukan untuk mengetahui pengaruh likuiditas, leverage, kebijakan dividen, ukuran
perusahaan, good corporate governance, dan sales growth terhadap nilai perusahaan pada perusahaan
manufaktur yang terdaftar di Indeks Saham Syariah Indonesia (ISSI) periode $2016-2020$. Populasi
penelitian adalah 121 perusahaan manufaktur yang terdaftar di Indeks Saham Syariah Indonesia (ISSI)
dengan periode penelitian selama 5 tahun. Metode pemilihan sampel adalah purposive sampling dan
terdapat 29 perusahaan yang sesuai dengan kriteria sampel. Metode analisis data menggunakan data
panel dan ordinary least squares (OLS). Hasil pengujian hipotesis menunjukkan bahwa secara parsial
likuiditas memiliki pengaruh negatif dan signifikan terhadap nilai perusahaan, kebijakan dividen
berpengaruh positif dan signifikan terhadap nilai perusahaan, ukuran perusahaan berpengaruh positif
dan signifikan terhadap nilai perusahaan, ukuran dewan komisaris berpengaruh negatif dan signifikan
terhadap nilai perusahaan, ukuran komite audit berpengaruh negatif dan signifikan terhadap nilai
perusahaan, dan sales growth berpengaruh negatif dan signifikan terhadap nilai perusahaan. Secara
simultan terdapat pengaruh yang signifikan dari likuiditas, leverage, kebijakan dividen, ukuran
perusahaan, ukuran dewan komisaris, ukuran komite audit, dan sales growth terhadap nilai perusahaan.


Kata kunci: Nilai Perusahaan, Likuiditas, Leverage, Kebijakan Dividen, Ukuran Perusahaan, Ukuran Dewan Komisaris, Ukuran Komite Audit, Sales Growth.

\section{Pendahuluan}

Perkembangan pasar modal syariah yang merupakan bagian dari pasar modal Indonesia setiap tahunnya menunjukkan trend positif, akan tetapi pada tahun 2020 terjadi ketidakstabilan pada pasar modal Indonesia. Bukan tanpa sebab, ketidakstabilan tersebut dipicu oleh Pandemi Covid-19 yang melanda seluruh dunia tidak terkecuali Indonesia. Dampak yang timbul dari kondisi tersebut menghambat operasionalisasi perusahaan dan aktivitas perekonomian sehingga berpengaruh di periode saat ini maupun periode yang akan datang, dan pada akhirnya perusahaan dihadapkan pada ketidakpastian.

Kinerja perusahaan dapat dicerminkan melalui nilai perusahaan. Nilai perusahaan yang baik akan membawa pengaruh untuk pasar serta menguatkan persepsi investor untuk berinvestasi di suatu perusahaan. Kinerja perusahaan yang baik akan menaikkan tingkat return sahamnya, dan pada akhirnya akan mempengaruhi kemakmuran pemilik yang tinggi [40]. Berdasarkan teori sinyal, naik turunnya nilai perusahaan akan menjadi sinyal bagi para investor sebagai indikator keberhasilan perusahaan, yang biasanya memiliki keterkaitan dengan harga saham suatu perusahaan. Selain itu, perusahaan juga harus dapat memperhatikan tingkat leverage yang dimiliki perusahaan, karena berdasarkan Trade Off Theory penggunaan utang yang terlalu tinggi akan mengurangi nilai perusahaan. Hal tersebut dikarenakan penggunaan utang yang terlalu tinggi akan meningkatkan biaya financial distress, dan akan mengindikasikan bahwa risiko perusahaan akan lebih tinggi sehingga akan berdampak negatif terhadap nilai perusahaan (Modigliani \& Miller, 1963) dalam [5]. Tidak hanya itu, perusahaan juga harus mampu memenuhi informasi yang diperlukan oleh para stakeholder guna menyeimbangkan kepentingan seluruh stakeholder sehingga kinerja berkelanjutan serta nilai jangka panjang perusahaan akan optimal.

Alasan peneliti menggunakan objek penelitian di perusahaan manufaktur yaitu karena perusahaan manufaktur terdiri dari 3 sub sektor industri yang keberadaannya memiliki peranan yang sangat strategis serta memiliki tingkat produksi yang berkelanjutan karena produk yang dihasilkan dari perusahaan manufaktur sangat diperlukan untuk memenuhi kebutuhan sehari-hari, sehingga naik turunnya variabel yang akan diteliti oleh penulis dapat mencerminkan nilai perusahaan. Berdasarkan penelitian-penelitian terdahulu yang menunjukkan hasil tidak konsisten dan faktor adanya fenomena pada periode penelitian menjadi alasan ketertarikan penulis untuk melakukan penelitian mengenai nilai perusahaan pada perusahaan manufaktur yang terdaftar di ISSI.

Teori yang digunakan dalam penelitian ini adalah teori keagenan, teori sinyal, trade off theory, dan bird in the hand theory. Teori keagenan dapat menjelaskan hubungan yang dimiliki baik antara manajemen perusahaan atau agen dengan pemilik atau prinsipal, yang mana secara etika memiliki tanggungjawab dalam melakukan optimalisasi keuntungan perusahaan atau keuntungan pemilik [41]. menyatakan bahwa ada tiga asumsi dalam teori keagenan, yaitu: (a) Asumsi tentang sifat manusia, yang didalamnya mencakup kepentingan pribadi, rasionalitas terbatas, dan penghindaran risiko; (b) Asumsi tentang keorganisasian, yang didalamnya mencakup 
menjadikan konflik sebagai tujuan dalam organisasi diantara peserta, pengefisienan menjadi kriteria efektivitas, dan informasi yang tidak simetris diantara prinsipal dan manajemen; dan (c) Asumsi terkait informasi [53]. Tujuan khusus dari teori keagenan adalah untuk mengungkap bagaimana para pihak menjalin hubungan kontraktual, tujuan lainnya adalah guna meminimalkan biaya akibat asimetri informasi dan kondisi ketidakpastian pengalaman sebagai bentuk kausalitas [14].

Pada praktiknya, teori sinyal menguraikan bagaimana manajemen dalam perusahaan memberi tanda kepada para shareholders terkait keberhasilan atau kegagalan pada manajemen. Dalam teori sinyal, agen atau manajemen harus mengirimkan sinyal keberhasilan kepada para shareholders melalui penyajian laporan keuangan perusahaan. Dari penyajian informasi keuangan tahunan tersebut diharapkan dapat memproyeksikan peningkatan pada profitabilitas serta perkembangan harga saham perusahaan [44]. Asimetri informasi diantara perusahaan dengan pihak eksternal (terutama investor dan kreditur) menjadi latar belakang munculnya teori sinyal. Sinyal dari perusahaan yang menghasilkan laba dapat diartikan bahwa perusahaan tidak rentan terhadap kemerosotan usaha ataupun bentuk lain dari financial distress, dibandingkan dengan perusahaan dengan laba yang lebih rendah [35].

Pada trade off theory, perusahaan diasumsikan akan menggunakan hutang hingga di tingkat tertentu guna mengoptimalkan nilai perusahaan melalui pemanfaatan pajak akibat penggunaan hutang. Titik optimal berdasarkan trade off theory ialah saat keguanaan dari utang yang meningkat lebih tinggi dari pengorbanan yang dikerahkan sehingga secara langsung kegunaan dari pemanfaatan hutang tersebut mendorong nilai perusahaan meningkat (Modigliani \& Miller, 1963) dalam [5]. Pada trade off theory juga dijelaskan bahwa penggunaan utang yang terlalu tinggi akan meningkatkan biaya financial distress, hal ini mengindikasikan bahwa risiko perusahaan juga akan lebih tinggi sehingga berdampak negatif terhadap nilai perusahaan khususnya yang diukur dengan price earning ratio.

Berdasarkan bird in the hand theory, apabila dilakukan peninjauan lebih jauh, dibandingkan dengan capital gain, investor cenderung menyukai dividen. Bukan tanpa sebab, teori tersebut juga menyatakan alasan dari situasi tersebut ialah karena tingkat kepastian pada dividen lebih tinggi dibandingkan dengan tingkat kepastian pada capital gain, sehingga jika tingkat pembagian dividen mengalami kenaikan maka akan meningkatkan pula nilai perusahaannya. Perusahaan yang rutin membagikan dividennya cenderung lebih disukai oleh para investor, apabila tingkat dividen yang didistribusikan perusahaan kepada para shareholders semakin tinggi, maka penilaian atas kinerja dari perusahaan tersebut baik. Ketika kinerja suatu perusahaan dinilai baik, maka perusahaan juga akan dianggap memiliki kapabilitas dalam memaksimalkan laba perusahaan, sehingga akan berdampak pada peningkatan harga saham yang juga menjadi cerminan dari nilai perusahaan [9].

Dalam aktivitas opersionalnya, setiap perusahaan memiliki tujuannya masingmasing. Secara umum, tujuan perusahaan mencakup tujuan pada jangka pendek dan jangka panjang. Tujuan jangka pendek bagi perusahaan yaitu memperoleh keuntungan dalam kegiatan operasionalnya serta memaksimalkan profit dengan penggunaan sumber daya yang efektif, kemudian untuk jangka panjang perusahaan memiliki tujuan untuk memaksimalkan nilai perusahaan [57]. Sejumlah harga yang harus dibayarkan 
oleh calon pembeli ketika suatu perusahaan dijual disebut dengan nilai perusahaan [9]. (Rosada dan Idayati, 2017) dalam [13] pada penelitiannya menyatakan bahwa nilai perusahaan memegang peranan yang krusial, karena tingginya nilai suatu perusahaan turut meningkatkan kapabilitas para shareholders. Adapun faktor-faktor yang menjadi indikator pengukuran nilai perusahaan antara lain, sebagai berikut [56]: (a) Earning Per Share (EPS); (b) Price Earning Ratio (PER); (c) Book Value per Share (BVS); (d) Price to Book Value (PBV); (e) Dividend Yield; dan (f) Dividend Payout Ratio (DPR).

Abdullah, Syariati dan Hamid dalam penelitiannya ia berpendapat bahwa tingginya tingkat likuiditas tidak serta merta membuktikan tersebarnya sinyal positif kepada para investor [2]. Tingginya tingkat likuiditas pada suatu perusahaan akan menandakan bahwa current asset pada perusahaan tersebut tidak digunakan dan menganggur. Namun, rendahnya tingkat likuiditas akan mengindikasikan jumlah aktiva tetap dalam perusahaan lebih besar dan nantinya akan memancarkan sinyal positif kepada para investor. Pada penelitian yang pernah dilakukan oleh [7], [3], [38], dan [20] menyebutkan bahwa variabel likuiditas berpengaruh positif signifian terhadap nilai perusahaan. Sedangkan, pada penelitian yang dilakukan oleh [30] dan [4] menyebutkan bahwa variabel likuiditas tidak berpengaruh terhadap nilai perusahaan. Sedangkan menurut [16] ia menyebutkan bahwa variabel likuiditas memiliki pengaruh yang negatif terhadap nilai perusahaan. Berdasarkan uraian di atas, dapat disusun hipotesis sebagai berikut:

H1: Likuiditas berpengaruh positif terhadap nilai perusahaan

Ross menyebutkan bahwa tingkat leverage memiliki hubungan yang positif terhadap nilai perusahaan, dimana tingkat leverage yang besar akan memberikan sinyal positif pada investor bahwa prospek perusahaan semakin bagus dan mempengaruhi nilai perusahaan di masa yang akan datang [45]. Sutama dan Lisa juga mengemukakan bahwa tingkat leverage yang tinggi dapat menjadi faktor meningkatnya nilai suatu perusahaan, begitupun sebaliknya, tingkat leverage yang rendah dapat menurunkan nilai perusahaan, hal tersebut menandakan bahwa tingginya tingkat leverage suatu perusahaan akan memperlihatkan peluang baik yang dimiliki perusahaan, dengan demikian hal tersebut dapat mendorong para investor untuk turut serta dalam menaikkan permintaan saham perusahaan [54]. Nilai perusahaan yang ikut meningkat merupakan cerminan dari tingginya permintaan saham perusahaan. Pada penelitian yang pernah dilakukan oleh [46], [22], [60], [45] dan [39] menyebutkan bahwa variabel leverage berpengaruh positif dan signifikan terhadap nilai perusahaan. Sedangkan, pada penelitian yang dilakukan oleh [6], [12], dan [24] menyebutkan bahwa variabel leverage berpengaruh negatif signifikan terhadap nilai perusahaan. Berdasarkan uraian di atas, dapat disusun hipotesis sebagai berikut:

H2: Leverage berpengaruh positif terhadap nilai perusahaan

Musabbihan dan Purnawati dalam penelitiannya mendukung bird in the hand theory dengan berpendapat bahwa adanya kepastian return dari aktivitas investasi serta antisipasi risiko atas ketidakpastian yang berkaitan dengan kebangkrutan perusahaan melalui pembagian dividen cenderung diminati oleh para investor [33]. Selanjutnya, risiko yang timbul dari pembagian dividen akan cenderung lebih rendah daripada capital gain, dengan demikian, tingginya tingkat pembayaran dividen suatu perusahaan akan meminimalisir biaya modal yang dikeluarkan sehingga akan 
berdampak pada peningkatan nilai suatu perusahaan. Pada penelitian yang dilakukan oleh [33], [10], dan [25] menunjukkan bahwa variabel kebijakan dividen berpengaruh positif signifikan positif terhadap nilai perusahaan. Di sisi lain, pada penelitian yang dilakukan oleh [20] menunjukkan bahwa variabel kebijakan dividen berpengaruh negatif dan signifikan terhadap nilai perusahaan. Berdasarkan uraian di atas, dapat disusun hipotesis sebagai berikut:

H3: Kebijakan dividen berpengaruh positif terhadap nilai perusahaan

Pratama dan Wiksuana dalam penelitiannya mengemukakan bahwa perkembangan dan pertumbuhan yang baik menjadi cerminan perusahaan besar, sehingga pada kondisi tersebut akan memiliki dampak pada peningkatan nilai perusahaannya [39]. Peningkatan pada nilai suatu perusahaan ditandai dari total aktiva suatu perusahaan yang meningkat lebih besar daripada total hutang perusahaannya. Pada penelitian yang telah dilakukan oleh [43], [7], [14], [12], dan [46] diperoleh hasil bahwa variabel ukuran perusahaan berpengaruh positif dan signifikan terhadap nilai perusahaan. Di sisi lain, penelitian yang dilakukan oleh [2] dan [36] menunjukkan bahwa variabel ukuran perusahaan memiliki pengaruh negatif terhadap nilai perusahaan. Berdasarkan uraian di atas, dapat disusun hipotesis sebagai berikut:

H4: Ukuran perusahaan berpengaruh positif terhadap nilai perusahaan

Sarafina dan Saifi dalam penelitiannya menyatakan bahwa dewan komisaris dalam melakukan tugas dan tanggung jawabnya harus profesional, profesional disini adalah memiliki integritas serta kemampuan sehingga dalam melaksanakan fungsinya dapat berjalan dengan baik termasuk dalam memastikan seluruh kepentingan pemangku kepentingan lainnya [49]. Tingginya tingkat jumlah dewan komisaris menunjukkan bahwa semakin rendah nilai perusahaannya, hal tersebut dilatarbelakangi oleh pengambilan keputusan yang tidak efektif karena terlalu banyaknya dewan komisaris. Sedangkan menurut teori [23] yang mengemukakan bahwa ukuran dewan komisaris memiliki pengaruh negatif terhadap nilai perusahaan karena semakin besar dewan komisaris maka semakin besar kecurngan dalam pelaporan keuangan sehingga akan menurunkan kualitas pengambilan keputusan sehingga akan memperburuk kinerja perusahaan dan mendorong penurunan pada nilai perusahaan. Pada penelitian yang dilakukan oleh [31], [49], [43], dan [41] menyatakan bahwa variabel ukuran dewan komisaris memiliki pengaruh positif dan signifikan terhadap nilai perusahaan. Sedangkan, pada penelitian yang dilakukan oleh [55] dan [23] menyebutkan bahwa variabel ukuran dewan komisaris berpengaruh negatif dan signifikan terhadap nilai perusahaan. Berdasarkan uraian di atas, dapat disusun hipotesis sebagai berikut:

H5: Ukuran dewan komisaris berpengaruh positif terhadap nilai perusahaan

Menurut Syafitri, Nuzula dan Nurlaily mengemukakan bahwa keberadaan komite audit diperlukan untuk mencegah adanya perilaku keagenan dalam perusahaan, sehingga terciptanya informasi yang berkaitan dengan keuangan perusahaan yang berkualitas, yang demikian akan memacu kepercayaan para investor yang sehingga nantinya akan memiliki dampak terhadap nilai suatu perusahaan yang meningkat [55]. McMullen menyebutkan bahwa komite audit memiliki hubungan yang positif terhadap nilai perusahaan, ia menyatakan bahwa investor, analisis, dan regulator beranggapan bahwa komite audit berkontribusi dalam kualitas laporan 
keuangan [32]. Laporan keuangan yang berkualitas akan memberikan sinyal positif bagi para investor sehingga akan mendorong peningkatan pada nilai perusahaan melalui peningkatan akan permintaan saham perusahaan. Pada penelitian yang dilakukan oleh [59], [60], [49], [55], [17], dan [43] menyebutkan bahwa variabel ukuran komite audit berpengaruh positif dan signifikan terhadap nilai perusahaan. Sedangkan, pada penelitian yang dilakukan oleh [35] hasil penelitiannya menunjukkan bahwa variabel ukuran komite audit memiliki pengaruh negatif dan signifikan terhadap nilai perusahaan. Berdasarkan uraian di atas, dapat disusun hipotesis sebagai berikut:

H6: Ukuran komite audit berpengaruh positif terhadap nilai perusahaan

Isnawati dan Widjajanti berpendapat bahwa sales growth diartikan sebagai alat ukur yang memiliki keterkaitan dengan bagaimana tingkat pertumbuhan perusahaan dalam suatu periode yang memperlihatkan performa perusahaan pada titik optimal sehingga akan berdampak pada peningkatan nilai perusahaan [21]. Sesuai dengan teori sinyal, suatu perusahaan yang tingkat sales growth-nya meningkat akan memberikan sinyal positif bagi para investor. Dengan sinyal tersebut, para calon investor akan semakin tertarik untuk berinvestasi di perusahaan tersebut. Kondisi tersebut dikarenakan calon investor tersebut memiliki kepercayaan atas pertumbuhan perusahaan yang akan terus meningkat diikuti dengan laba yang turut mengalami peningkatan juga. Meningkatnya tingkat sales growth yang berkesinambungan akan menjadi daya tarik tersendiri bagi para calon investor untuk berinvestasi. Sehingga kondisi tersebut akan mendorong harga saham perusahaan meningkat sebagai refleksi atas nilai perusahaan. Pada penelitian yang dilakukan oleh [47], [19], dan [26] diperoleh hasil bahwa variabel sales growth berpengaruh positif dan signifikan terhadap nilai perusahaan. Sedangkan pada penelitian [8] diperoleh hasil bahwa variabel sales growth berpengaruh negatif dan signifikan terhadap nilai perusahaan. Berdasarkan uraian di atas, dapat disusun hipotesis sebagai berikut:

H7: Sales growth berpengaruh positif terhadap nilai perusahaan

\section{Kerangka Pemikiran}

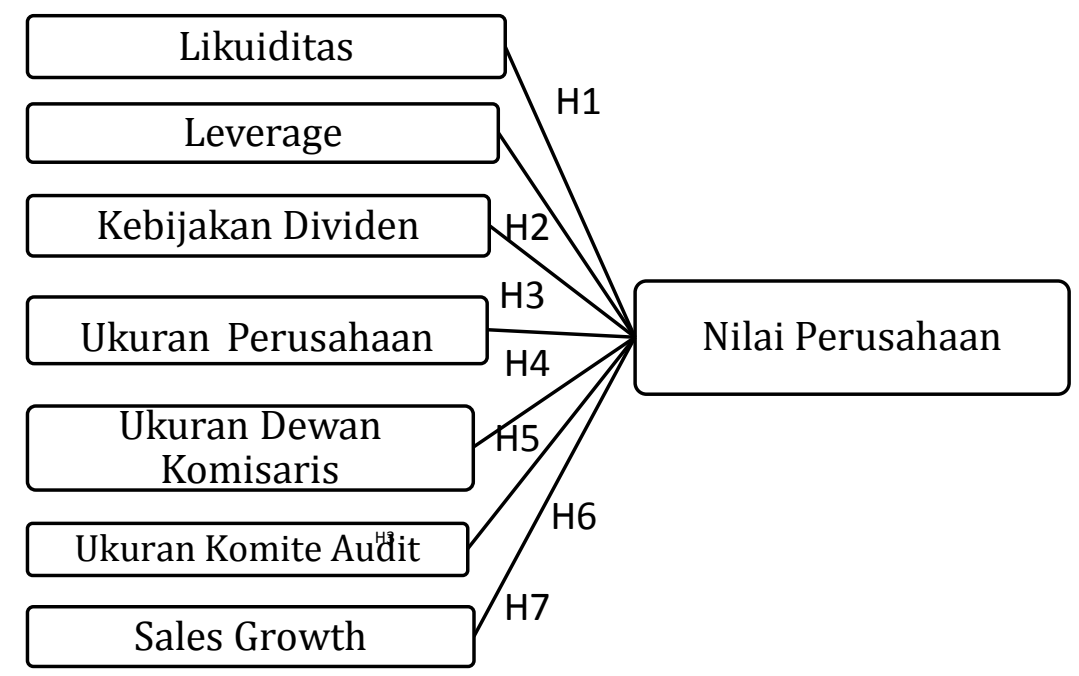

Gambar 1. Kerangka Pemikiran 


\section{Metode Penelitian}

Pada penelitian ini data yang digunakan diperoleh dari laporan keuangan dan laporan tahunan pada perusahaan manufaktur yang terdaftar di Indeks Saham Syariah Indonesia sepanjang tahun 2016 sampai dengan 2020. Data penelitian ini menggunakan jenis data sekunder. Purposive sampling diterapkan dalam penentuan sampel penelitian ini dengan memperhatikan kriteria tertentu. Kriteria yang dimaksud adalah sebagai berikut:

1. Perusahaan manufaktur yang terdaftar di Daftar Efek Syariah periode 2016 2020 dan tidak delisting selama periode tersebut.

2. Perusahaan manufaktur yang membagikan dividen tunai berturut-turut sepanjang periode 2016 - 2020.

3. Perusahaan manufaktur yang menggunakan satuan rupiah dalam laporan keuangannya.

4. Perusahaan manufaktur yang mempublikasikan laporan tahunan dan laporan keuangan berturut-turut selama periode 2016 - 2020.

Berdasarkan kriteria tersebut, terdapat 29 perusahaan yang dapat memenuhi kriteria dengan periode penelitian 5 tahun, sehingga terdapat 145 laporan keuangan perusahaan sebagai total data yang akan digunakan dalam penelitian. Nilai perusahaan merupakan variabel terikat (independen) dalam penelitian ini sedangkan variabel bebas yang dapat mempengaruhinya adalah likuiditas, leverage, kebijakan dividen, ukuran perusahaan, ukuran dewan komisaris, ukuran komite audit, dan sales growth.

\section{Nilai Perusahaan}

Nilai perusahaan diartikan sebagai nilai pasar yang direfleksikan melalui performa perusahaan yang terlihat dari harga sahamnya [11]. Proksi dari nilai perusahaan yang digunakan adalah Price Earning Ratio, yang dirumuskan sebagai berikut:

$$
P E R=\frac{\text { Harga Saham }}{\text { Earning Per Share }} \times 100 \%
$$

\section{Likuiditas}

Likuiditas merupakan salah satu indikator yang memiliki keterkaitan dengan kapabilitas suatu perusahaan atas tanggungjawabnya dalam menyelesaikan seluruh kewajiban jangka pendeknya saat jatuh tempo melalui aktiva lancar yang tersedia [28]. Dalam penelitian ini current ratio menjadi alat ukur dalam menilai tingkat likuiditas pada perusahaan-perusahaan yang diteliti. Adapun rumusnya, sebagai berikut [15]:

$$
\text { Current Ratio }=\frac{\text { Current Asset }}{\text { Current Liabilities }} \times 100 \%
$$

\section{Leverage}

Leverage menjadi rasio yang dapat menghitung seberapa tinggi perusahaan menggunakan permodalan yang berasal dari hutang [50]. Debt to Equity Ratio digunakan sebagai rasio pengukuran variabel leverage. Adapun rumus perhitungan dari rasio leverage adalah sebagai berikut [9]:

$$
\text { Debt to Equity Ratio }=\frac{\text { Total Hutang }}{\text { Total Ekuitas }} \times 100 \%
$$




\section{Kebijakan Dividen}

Suatu ketetapan yang menentukan apakah profit yang diperoleh perusahaan pada akhir periode akan dibayarkan oleh perusahaan kepada para shareholders di tahun yang akan datang diartikan sebagai kebijakan dividen [20]. Pada penelitian ini, variabel kebijakan dividen diproksikan dengan DPR (Dividend Payout Ratio), adapun rumus yang digunakan dalam menghitung DPR, yaitu [34]:

$$
\text { Dividend Payout Ratio }=\frac{\text { Dividend Per Share }}{\text { Earning Per Share }} \times 100 \%
$$

\section{Ukuran Perusahaan}

Dalam mengklasifikasikan besar kecilnya ukuran suatu perusahaan digunakanlah skala untuk mengukur agar dapat menentukan klasifikasi perusahaan, adapun metode untuk mengukurnya dapat ditinjau dari nilai total aset perusahaan, nilai logaritma dari total aset perusahaan, nilai pasar saham, dan sebagainya [22]. Proksi yang digunakan untuk melihat tingkat ukuran perusahaan dalam penelitian ini adalah sebagai berikut [38]:

$$
\text { Size }=\operatorname{Ln}(\text { Total Aset })
$$

\section{Ukuran Dewan Komisaris}

Jumlah keseluruhan anggota yang menduduki jabatan sebagai dewan komisaris suatu perusahaan pada periode tertentu dan dihitung berdasarkan jumlah satuan disebut dengan ukuran dewan komisaris [58].

$$
\text { Ukuran Dewan Komisaris }=\sum \text { anggota dewan komisaris }
$$

\section{Ukuran Komite Audit}

Komite yang memiliki kewenangan dalam mengawasi dan mengelola laporan-laporan yang berkaitan dengan keuangan perusahaan serta sistem pengendalian intern dan pengimplementasian skema pencatatan akuntansi yang diterima secara publik, serta mengontrol integritas prosedur merupakan definisi dari komite audit [55].

\section{Sales Growth}

$$
\text { Ukuran Komite Audit }=\sum \text { anggota komite audit }
$$

Sales growth diartikan sebagai sebuah indikator yang menggambarkan bagaimana perkembangan perusahaan pada suatu periode tertentu yang memperlihatkan performa perusahaan pada titik optimal yang akan memiliki dampak pada nilai perusahaan yang meningkat [21]. Adapun rumus penghitungan dari sales growth ialah [41]:

$$
\text { Sales Growth }=\frac{\text { Penjualan }_{t}-\text { Penjualan }_{t-1}}{\text { Penjualan }_{t-1}} \times 100 \%
$$




\section{Hasil Dan Pembahasan}

\section{Analisis Deskriptif}

Penelitian ini menggunakan variabel dependen yaitu nilai perusahaan serta tujuh variabel independen yaitu likuiditas, leverage, kebijakan dividen, ukuran perusahaan, ukuran dewan komisaris, ukuran komite audit, dan sales growth. Berikut ini adalah hasil analisis deskriptif dari masing-masing variabel penelitian:

Tabel 1. Analisis Deskriptif

\begin{tabular}{|l|r|r|r|r|r|r|r|r|}
\hline & \multicolumn{1}{|c|}{ PER } & \multicolumn{1}{c|}{ CR } & \multicolumn{1}{c|}{ DER } & \multicolumn{1}{c|}{ DPR } & \multicolumn{1}{c|}{ SIZE } & \multicolumn{1}{l|}{ UDK } & \multicolumn{1}{c|}{ UKA } & \multicolumn{1}{c|}{ GROWTH } \\
\hline Mean & 45.78 & 2.74 & 0.67 & 0.45 & 29.12 & 4.39 & 3.02 & 0.04 \\
\hline Maximum & 2372.34 & 8.31 & 3.16 & 1.77 & 32.70 & 8.00 & 5.00 & 0.86 \\
\hline Minimum & -80.13 & 0.60 & 0.01 & 0.01 & 26.71 & 2.00 & 2.00 & -4.11 \\
\hline Std. Dev. & 214.81 & 1.51 & 0.56 & 0.29 & 1.42 & 1.83 & 0.35 & 0.38 \\
\hline Observations & 145 & 145 & 145 & 145 & 145 & 145 & 145 & 145 \\
\hline
\end{tabular}

Sumber: Olah Data Sekunder

Variabel Y dalam penelitian ini merupakan nilai perusahaan yang diproksikan oleh Prcie Earning Ratio (PER). Berdasarkan tabel di atas, rata-rata untuk variabel Y ini adalah 45,78\%. Hal ini berarti bahwa dalam satu periode laporan keuangan, perusahaan rata-rata memiliki nilai PER sebesar 45,78\%. Nilai PER paling rendah terjadi di tahun 2020 dengan nilai $-80,13 \%$ sedangkan nilai perusahaan tertinggi terjadi di tahun 2020 dengan nilai 2372,34\%.

Variabel likuiditas dalam penelitian ini yang diproksikan oleh Current Ratio (CR) menunjukkan nilai rata-rata sebesar 2,74 atau $274 \%$. Nilai CR terendah terjadi di tahun 2016 dengan nilai 0,60 atau $60 \%$ sedangkan likuiditas tertinggi terjadi di tahun 2016 dengan nilai 8,31 atau 831\%. Variabel leverage dalam penelitian ini yang diproksikan oleh Debt to Equity Ratio (DER) menunjukkan nilai rata-rata sebesar 0,67 atau 67\%. Nilai DER terendah terjadi di tahun 2020 dengan nilai 0,01 atau 1\% sedangkan tingkat leverage tertinggi terjadi di tahun 2020 dengan nilai 3,16 atau 316\%. Variabel kebijakan dividen dalam penelitian ini yang diproksikan oleh Dividend Payout Ratio (DPR) menunjukkan nilai rata-rata sebesar 0,45 atau 45\%. Nilai DPR terendah terjadi di tahun 2019 dengan nilai 0,01 atau 1\% sedangkan kebijakan dividen tertinggi terjadi di tahun 2018 dengan nilai 1,77 atau 177\%. Variabel ukuran perusahaan dalam penelitian ini menunjukkan nilai rata-rata sebesar 29,12. Nilai ukuran perusahaan terendah terjadi di tahun 2016 dengan nilai 26,71 sedangkan ukuran perusahaan tertinggi terjadi di tahun 2020 dengan nilai 32,70. Variabel ukuran dewan komisaris dalam penelitian ini menunjukkan nilai rata-rata sebesar 4,39. Nilai ukuran dewan komisaris terendah terjadi di tahun 2016 dengan nilai 2,00 sedangkan ukuran dewan komisaris tertinggi terjadi di tahun 2018 dengan nilai 8,00. Variabel ukuran komite audit dalam penelitian ini menunjukkan nilai rata-rata sebesar 3,02. Nilai ukuran komite audit terendah terjadi di tahun 2016 dengan nilai 2,00 sedangkan ukuran komite audit tertinggi terjadi di tahun 2016 dengan nilai 5,00. Variabel sales growth dalam penelitian ini menunjukkan nilai rata-rata 0,04 atau $4 \%$. Nilai sales 
growth terendah terjadi di tahun 2020 dengan nilai $-0,04 \%$ atau $-4 \%$ sedangkan sales growth tertinggi terjadi di tahun 2020 dengan nilai 0,86 atau 86\%.

\section{Hasil Uji Normalitas}

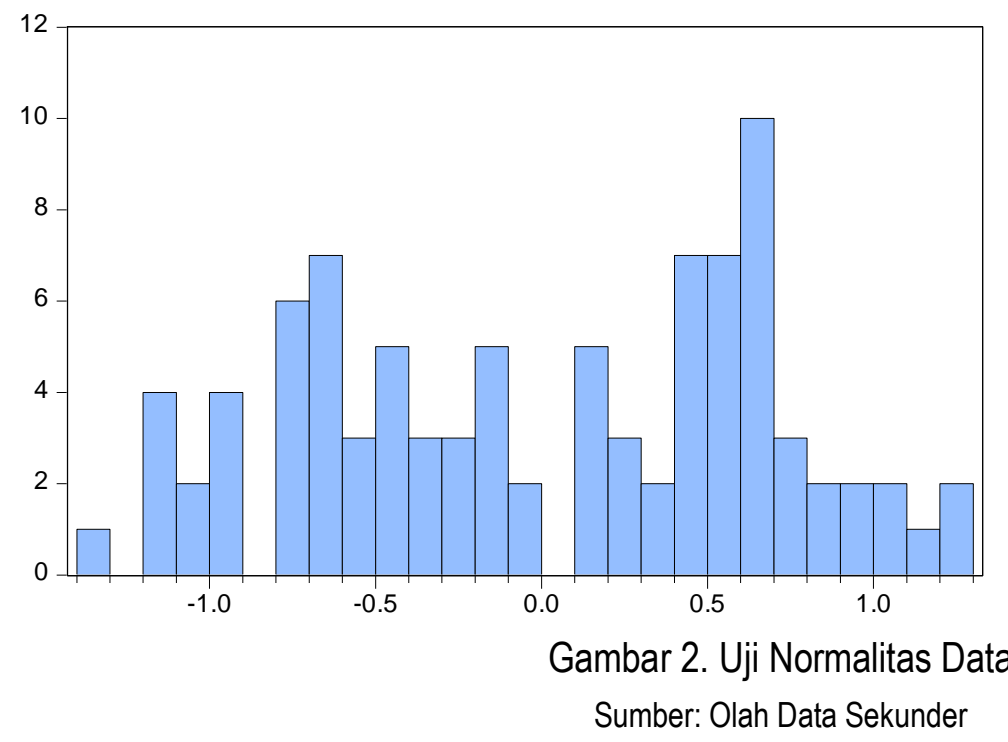

Series: Residuals

Sample 20162020

Observations 145

Mean $\quad-1.86 \mathrm{e}-16$

Median $\quad 0.100051$

Maximum $\quad 1.293817$

Minimum $\quad-1.337925$

Std. Dev. $\quad 0.682885$

Skewness $\quad-0.103501$

Kurtosis $\quad 1.806784$

Jarque-Bera $\quad 5.560912$

Probability $\quad 0.062010$

Hasil uji normalitas dalam program Eviews di atas terlihat nilai probability Jarque-Bera sebesar $0,0620>0,05(\alpha=5 \%)$, sehingga dapat disimpulkan bahwa data pada penelitian ini terdistribusi secara normal.

\section{Hasil Uji Multikolinearitas}

Tabel 2. Uji Multikolinearitas

\begin{tabular}{llll}
\hline \hline Variable & $\begin{array}{l}\text { Coefficient } \\
\text { Variance }\end{array}$ & $\begin{array}{l}\text { Uncentered } \\
\text { VIF }\end{array}$ & $\begin{array}{l}\text { Centered } \\
\text { VIF }\end{array}$ \\
\hline \hline $\mathrm{C}$ & 2.332801 & 682.2958 & NA \\
$\mathrm{CR}$ & 0.002835 & 8.133098 & 1.899546 \\
DER & 0.019275 & 4.370977 & 1.775368 \\
DPR & 0.044491 & 3.821292 & 1.145669 \\
LNSIZE & 0.003715 & 924.1179 & 2.196419 \\
UKA & 0.031956 & 86.82492 & 1.153131 \\
UDK & 0.002158 & 14.29281 & 2.109716 \\
LNGROWTH & 0.024481 & 1.065133 & 1.051610 \\
\hline \hline
\end{tabular}

Sumber: Olah Data Sekunder

Berdasarkan pengujian multikolinearitas pada tabel di atas, hasilnya menyatakan bahwa semua variabel menunjukkan nilai VIF $<10$. Jadi, kesimpulan dalam penelitian ini pada model regresi tidak terjadi multikolinearitas. 


\section{Hasil Uji Heteroskedastisitas}

Tabel 3. Uji Heteroskedastisitas

Heteroskedasticity Test: White

\begin{tabular}{llll}
\hline \hline F-statistic & 1.079518 & Prob. F(7,137) & 0.3798 \\
Obs ${ }^{*}$ R-squared & 7.579803 & Prob. Chi-Square(7) & 0.3711 \\
Scaled explained SS & 3.779181 & Prob. Chi-Square(7) & 0.8048 \\
\hline \hline
\end{tabular}

Sumber: Olah Data Sekunder

Pada output di atas terlihat bahwa nilai probabilitas yang ditunjukkan dengan nilai Probabilitas Chi-Square pada Obs*R-Squared yaitu sebesar 0,3711. Oleh karena nilai probabilitas 0,3711 >0,05 maka model regresi bersifat homoskedastisitas, sehingga pada model tidak terdapat heteroskedastisitas.

\section{Hasil Uji Autokorelasi}

Tabel 4. Uji Autokorelasi

\begin{tabular}{|c|c|}
\hline Durbin-Watson stat & 1,995900 \\
\hline
\end{tabular}

Sumber: Olah Data Sekunder

Pada output di atas diperoleh hasil Durbin-Watson Statistic sebesa 1,99. Dan berdasarkan kriteria pengambilan keputusan menurut [28] dimana jika nilai Durbinwatson diantar -2 sampai dengan 2 berarti tidak ada autokorelasi. Maka, dapat disimpulkan bahwa pada model regresi yang digunakan terbebas dari gangguan autokorelasi.

\section{Hasil Uji Pemilihan Model}

\section{Hasil Uji Chow}

Tabel 5. Uji Chow

\begin{tabular}{lrrrr}
$\begin{array}{l}\text { Redundant Fixed Effects Tests } \\
\text { Equation: Untitled }\end{array}$ & & & & \\
Test cross-section fixed effects & & & & \\
\hline \hline Effects Test & Statistic & & d.f. & Prob. \\
\hline \hline Cross-section F & 0.756739 & & $(27,56)$ & 0.7831 \\
Cross-section Chi-square & 28.305480 & & 27 & 0.3954 \\
\hline \hline
\end{tabular}

Sumber: Olah Data Sekunder

Hasil uji chow pada tabel di atas menunjukkan bahwa nilai prob. Cross-section Chisquare $>0,05(0,39>0,05)$, sehingga model yang terpilih adalah Common Effect. Berdasarkan hasil Uji Chow yang telah dilakukan, model yang terpilih adalah Common 
Effect Model (CEM). Adapun persamaan regresi dengan menggunakan Common Effect Model adalah sebagai berikut:

Tabel 6. Analisis Regresi Common Effect Model (CEM)

\begin{tabular}{crrrr}
\hline \hline Variable & Coefficient & Std. Error & t-Statistic & Prob. \\
\hline \hline C & 1.099903 & 1.725940 & 0.637277 & 0.0257 \\
CR & -0.184757 & 0.064460 & -2.866225 & 0.0053 \\
DER & -0.293573 & 0.158946 & -1.846997 & 0.0083 \\
DPR & 0.404804 & 0.171428 & 2.361365 & 0.0206 \\
LNSIZE & 0.013365 & 0.066267 & 2.201688 & 0.0407 \\
UDK & -0.137599 & 0.054124 & -2.542287 & 0.0129 \\
UKA & -0.102117 & 0.240351 & -0.424868 & 0.0270 \\
\multicolumn{1}{c}{ LNGROWTH } & -0.092380 & 0.172528 & -0.535447 & 0.0338 \\
\hline \hline & & & & \\
\hline \hline R-squared & 0.886893 & Mean dependent var & & 2.119278 \\
Adjusted R-squared & 0.818318 & S.D. dependent var & & 3.760054 \\
S.E. of regression & 0.932662 & Sum squared resid & & 60.97995 \\
F-statistic & 47.2575370 & Durbin-Watson stat & & 2.139471 \\
Prob(F-statistic) & 0.013521 & & & \\
\hline \hline
\end{tabular}

Sumber: Olah Data Sekunder

Berdasarkan hasil regresi di atas diperoleh persamaan:

$$
\begin{gathered}
\text { LNPER = 1,0999 - 0,1847CR-0,2935 DER + 0,4048 DPR +0,0134 LnSize } \\
-0,1376 \text { UDK }-0,1021 \text { UKA - 0,0924 LnGrowth }+e
\end{gathered}
$$

\section{Hasil Uji F}

Berdasarkan tabel analisis regresi dengan Common Effect Model di atas dapat diketahui bahwa F-statistik atau $F_{\text {hitung }}$ sebesar 47,257 dengan nilai probabilitas 0,0135. Nilai probabilitas tersebut lebih kecil dari $\alpha=5 \%$. Selain itu, dengan $\mathrm{n}=145 \mathrm{dan} \mathrm{k}=7$, nilai $F_{\text {tabel }}$ diperoleh sebesar 2,16 dengan df1 (k-1) $=6$ dan df2 (n-k) = 138 dengan nilai kritis 5\%. Karena $F_{\text {hitung }}>F_{\text {tabel }}(47,2573>2,16)$ dan nilai probabilitas $<0,05(0,0135$ $<0,05$ ) maka dapat disimpulkan bahwa variabel likuiditas, leverage, kebijakan dividen, ukuran perusahaan, ukuran dewan komisaris, ukuran komite audit, dan sales growth berpengaruh signifikan terhadap nilai perusahaan.

\section{Hasil Uji $\mathbf{R}^{2}$}

Berdasarkan tabel 6, diketahui bahwa nilai adjusted R-squared sebesar 0,818318. Hal ini menunjukkan bahwa variasi variabel terikat yaitu Nilai perusahaan dapat 
dijelaskan oleh variabel bebas yaitu likuiditas, leverage, kebijakan dividen, ukuran perusahaan, ukuran dewan komisaris, ukuran komite audit, dan sales growth sebesar $81,83 \%$ sedangkan sisanya $18,17 \%$ dipengaruhi oleh faktor lain di luar variabel yang diteliti.

\section{Hasil Uji t}

Hasil pengujian variabel likuiditas terhadap nilai perusahaan menunjukkan hasil output dengan nilai probabilitas $<0,05(0,0053<0,05)$ dan nilai koefisien sebesar 0,1847 . Output tersebut menunjukkan bahwa likuiditas yang diproksikan oleh Current Ratio (CR) berpengaruh negatif dan signifikan terhadap nilai perusahaan pada perusahaan manufaktur yang listing di ISSI. Hasil ini menunjukkan bahwa ketika aktiva lancar yang dimiliki perusahaan semakin tinggi, berarti ada dana yang menganggur di perusahaan sehingga akan mengakibatkan perusahaan tidak dapat secara optimal memanfaatkan aktiva lancarnya, kondisi tersebut akan mencerminkan bahwa perusahaan tidak mampu memakmurkan para pemegang sahamnya. Padahal untuk meningkatkan nilai perusahaan, perusahaan harus bisa memakmurkan pemegang sahamnya [52]. Hasil penelitian ini selaras dengan penelitian yang dilakukan oleh [1] dengan hasil yang menjelaskan bahwa likuiditas memiliki pengaruh negatif dan signifikan terhadap nilai perusahaan. Akan tetapi, hasil penelitian ini berbanding terbalik dengan hasil penelitian [37] dan [15].

Hasil pengujian variabel leverage terhadap nilai perusahaan menunjukkan hasil output dengan nilai probabilitas $<0,05(0,0083<0,05)$ dan nilai koefisien sebesar 0,2936. Output tersebut menunjukkan bahwa leverage yang diproksikan oleh Debt to Equity Ratio (DER) berpengaruh negatif dan signifikan terhadap nilai perusahaan pada perusahaan manufaktur yang listing di ISSI. Hasil ini sejalan dengan trade off theory yang menyatakan bahwa penggunaan utang yang terlalu tinggi akan mengurangi nilai perusahaan. Penggunaan utang yang terlalu tinggi akan meningkatkan biaya financial distress, hal ini mengindikasikan bahwa risiko perusahaan juga akan lebih tinggi sehingga berdampak negatif terhadap nilai perusahaan khususnya yang diukur dengan nilai perusahaan. Hasil penelitian ini selaras dengan penelitian sebelumnya yang dilakukan oleh [18], dan [6] arizki yang menyatakan bahwa leverage berpengaruh negatif dan signifikan terhadap nilai perusahaan. Akan tetapi, hasil penelitian ini berbanding terbalik dengan hasil penelitian [60].

Hasil pengujian variabel kebijakan dividen terhadap nilai perusahaan menunjukkan hasil output dengan nilai probabilitas $<0,05(0,0206<0,05)$ dan nilai koefisien sebesar 0,4048. Output tersebut menunjukkan bahwa kebijakan dividen yang diproksikan oleh Dividend Payout Ratio (DPR) berpengaruh positif dan signifikan terhadap nilai perusahaan pada perusahaan manufaktur yang listing di ISSI. Hasil penelitian ini selaras dengan teori bird in the hand yang menyatakan bahwa para pemegang saham lebih menyukai pembagian laba dalam bentuk dividen dibandingkan capital gain. Sejalan dengan itu, hal ini sesuai dengan hipotesis bahwa perusahaan dengan pembayaran dividen yang besar kepada pemegang sahamnya dapat 
meningkatkan nilai perusahaan, karena investor akan menginvestasikan dananya pada suatu perusahaan yang membagikan labanya dalam bentuk dividen secara konsisten [25]. Hasil penelitian ini didukung oleh peneliti terdahulu yang dilakukan oleh [42] dengan hasil yang menjelaskan bahwa kebijakan dividen berpengaruh positif terhadap nilai perusahaan.

Hasil pengujian variabel ukuran perusahaan terhadap nilai perusahaan menunjukkan hasil output dengan nilai probabilitas $<0,05(0,0407<0,05)$ dan nilai koefisien sebesar 0,0134 . Output tersebut menunjukkan bahwa ukuran perusahaan berpengaruh positif dan signifikan terhadap nilai perusahaan pada perusahaan manufaktur yang listing di ISSI. Hasil penelitian ini membuktikan bahwa semakin besar ukuran perusahaan maka semakin besar pula nilai perusahaan dan jika semakin kecil ukuran perusahaan maka semakin kecil pula nilai perusahaan. Nilai perusahaan yang meningkat dapat ditandai dengan total aktiva perusahaan manufaktur yang mengalami kenaikan dan lebih besar dibandingkan dengan jumlah hutang perusahaan [38]. Oleh karena itu, ukuran perusahaan yang ditinjau dari total aset yang tinggi akan mendorong peningkatan pada nilai perusahaan. Hasil penelitian ini didukung oleh peneliti terdahulu [14] dengan hasil penelitian yang menjelaskan bahwa ukuran perusahaan memiliki pengaruh positif dan signifikan terhadap nilai perusahaan.

Hasil pengujian variabel ukuran dewan komisaris terhadap nilai perusahaan menunjukkan hasil output dengan nilai probabilitas $<0,05(0,0129<0,05)$ dan nilai koefisien sebesar -0,1376. Output tersebut menunjukkan bahwa ukuran dewan komisaris berpengaruh negatif dan signifikan terhadap nilai perusahaan pada perusahaan manufaktur yang listing di ISSI. Hasil penelitian ini membuktikan bahwa semakin tinggi jumlah anggota dewan komisaris justru akan menurunkan nilai perusahaan dan sebaliknya. Hal tersebut dikarenakan semakin banyak anggota dewan komisaris maka pengambilan keputusan dalam suatu perusahaan akan semakin tidak efektif [55]. Hasil penelitian ini didukung oleh peneliti terdahulu [55] yang menyatakan bahwa ukuran dewan komisaris berpengaruh negatif dan signifikan terhadap nilai perusahaan. Akan tetapi, hasil penelitian ini berbanding terbalik dengan penelitian yang dilakukan oleh [49].

Hasil pengujian variabel ukuran komite audit terhadap nilai perusahaan menunjukkan hasil output dengan nilai probabilitas $<0,05(0,0270<0,05)$ dan nilai koefisien sebesar -0,1021. Output tersebut menunjukkan bahwa ukuran komite audit berpengaruh negatif dan signifikan terhadap nilai perusahaan pada perusahaan manufaktur yang listing di ISSI. Hasil penelitian ini membuktikan bahwa jumlah anggota komite audit yang semakin banyak tidak menjadi jaminan bahwa kinerja suatu perusahaan juga akan meningkat. Anggota komite audit yang terlalu banyak berakibat kurang baik bagi perusahaan karena akan ada banyak tugas atau pekerjaan yang terpecah. Hal ini menyebabkan anggota komite audit kurang fokus dalam menjalankan tugasnya sehingga kinerja perusahaan akan semakin memburuk [51]. Hasil penelitian ini didukung oleh penelitian [35] dengan hasil penelitian yang menjelaskan bahwa ukuran komite audit berpengaruh negatif dan signifikan terhadap nilai perusahaan. 
Akan tetapi, hasil penelitian ini berbanding terbalik dengan penelitian yang dilakukan oleh [55].

Hasil pengujian variabel sales growth terhadap nilai perusahaan menunjukkan hasil output dengan nilai probabilitas $<0,05(0,0338<0,05)$ dan nilai koefisien sebesar $-0,0924$. Output tersebut menunjukkan bahwa sales growth berpengaruh negatif dan signifikan terhadap nilai perusahaan pada perusahaan manufaktur yang listing di ISSI. Hasil penelitian ini membuktikan bahwa pertumbuhan penjualan yang tinggi jika tidak diikuti oleh receivable turnover yang tinggi pula, justru akan menjadi sinyal negatif bagi pasar, karena akan mengganggu cash flow. Alasan lainnya ialah karena tingkat penjualan yang tinggi dikhawatirkan justru perusahaan sedang berada pada titik puncak cycle product. Akibatnya, pada kondisi ini dikahawatirkan perusahaan sudah tidak dapat tumbuh lagi. Kekhawatiran ini yang mengurungkan minat investor untuk berinvestasi pada perusahaan tersebut, akibatnya nilai perusahaan akan menurun [8]. Hasil penelitian ini didukung oleh penelitian [8] dan [29] dengan hasil penelitian yang menjelaskan bahwa sales growth berpengaruh negatif dan signifikan terhadap nilai perusahaan. Akan tetapi, hasil penelitian ini berbanding terbalik dengan penelitian yang dilakukan oleh [47].

\section{Kesimpulan Dan Saran}

Berdasarkan hasil penelitian dan pembahasan di atas, maka dapat ditarik kesimpulan yaitu variabel likuiditas, leverage, ukuran dewan komisaris, ukuran komite audit, dan sales growth berpengaruh negatif terhadap nilai perusahaan. Sedangkan, variabel kebijakan dividen dan ukuran perusahaan berpengaruh positif terhadap nilai perusahaan.

Keterbatasan yang terdapat dalam penelitian yaitu periode pengamatan yang terbatas sehingga masih diperlukan data untuk mendapatkan hasil yang signifikan. Selain itu, hasil dari pengujian $R$ Squared menunjukkan hanya 82,34\% yang mempengaruhi Nilai Perusahaan sehingga terdapat 17,66\% dapat dijelaskan oleh variabel di luar penelitian. Atas keterbatasan tersebut, disarankan untuk penelitian selanjutnya yang memakai objek penelitian berbeda seperti pertambangan, perbankan, atau BUMN dapat memberikan variasi jumlah sampel, periode pengamatan, dan menggunakan variabel lain yang dapat berpengaruh terhadap Nilai Perusahaan seperti Return on Asset (ROA), Inflasi, atau nilai tukar rupiah. Hasil penelitian ini berkontribusi sebagai bahan pertimbangan para investor sebelum memutuskan untuk menanamkan modalnya di perusahaan manufaktur dan juga berkontribusi bagi perusahaan sebagai bahan pertimbangan dalam upaya meningkatkan nilai perusahaan.

\section{Referensi}

[1] Aji, A. W., \& Atun, F. F. (2019). Pengaruh Tax Planning, Profitabilitas, dan Likuiditas terhadap Nilai Perusahaan dengan Ukuran Perusahaan Sebagai Variabel Moderasi (Studi Kasus Perusahaan Manufaktur yang Terdaftar di 
Bursa Efek Indonesia Tahun 2014-2018). Jurnal Ilmiah Akuntansi Dan Humanika, 9(3), 222-234.

[2] Abdullah, W., Syariati, A., \& Hamid, R. (2017). Pengaruh Corporate Social Responsibility (CSR), Ukuran Perusahaan, dan Interest Based Debt (IBD) terhadap Nilai Perusahaan Pada Perusahaan Manufaktur di Jakarta Islamic Index Periode 2010-2016. Jurnal MINDS: Manajemen Ide Dan Inspirasi, 4(2).

[3] Agustina, A. (2020). Pengaruh Pengungkapan Islamic Social Reporting, Profitabilitas, dan Likuiditas terhadap Nilai Perusahaan (Studi Empiris Pada Perusahaan yang Terdaftar di Jakarta Islamic Index Pada Bursa Efek Indonesia). Indonesian Interdisciplinary Journal of Sharia Economics (IIJSE), 3(1), 69-84.

[4] Alifiani, R. A., Sutopo, S., \& Noviandari, I. (2020). Pengaruh Profitabilitas, Likuiditas Dan Kebijakan Dividen terhadap Nilai Perusahaan Manufaktur yang Terdaftar Di Bursa Efek Indonesia (BEI). EkoBis: Jurnal Ekonomi \& Bisnis, 5(1), 62-81.

[5] Apriliyanti, V., Hermi, \& Herawaty, V. (2019). Pengaruh Kebijakan Hutang, Kebijakan Dividen, Profitabilitas, Pertumbuhan Penjualan dan Kesempatan Investasi terhadap Nilai Perusahaan dengan Ukuran Perusahaan Sebagai Variabel Moderasi. Jurnal Magister Akuntansi Trisakti, 6(2), 201-224.

[6] Arizki, A., Masdupi, E., \& Zulvia, Y. (2019). Pengaruh Keputusan Investasi, Keputusan Pendanaan dan Kebijakan Dividen terhadap Nilai Perusahaan pada Perusahaan Manufaktur. Jurnal Kajian Manajemen Dan Wirausaha, 01(01), 7382.

[7] Astuti, N. K. B., \& Yadnya, I. P. (2019). Pengaruh Profitabilitas, Likuiditas, Dan Ukuran Perusahaan terhadap Nilai Perusahaan Melalui Kebijakan Dividen. EJurnal Manajemen Universitas Udayana, 5(7), 4044-4070.

[8] Astutik, D. (2017). Pengaruh Aktivitas Rasio Keuangan terhadap Nilai Perusahaan (Studi Pada Industri Manufaktur). Jurnal STIE Semarang, 9(1).

[9] Bintari, V. I., \& Kusnandar, D. L. (2020). Analisis Faktor-Faktor yang Mempengaruhi Nilai Perusahaan. Jurnal Bisnis Dan Manajemen, 27(1), 89-99.

[10] Cahyaningdyah, D., \& Ressany, Y. D. (2012). Pengaruh Kebijakan Manajemen Keuangan terhadap Nilai Perusahaan. Jurnal Dinamika Manajemen, 3(1), 20-28.

[11] Dianawati, C. P., \& Fuadati, S. R. (2016). Pengaruh CSR Dan GCG Terhadap Nilai Perusahaan: Profitabilitas Sebagai Variabel Intervening. Jurnal Ilmu Dan Riset Manajemen, 5(1), 1-20.

[12] Ernawati, D., \& Widyawati, D. (2015). Pengaruh Profitabilitas, Leverage, dan Ukuran Perusahaan terhadap Nilai Perusahaan. Jurnal Ilmu Dan Riset Akuntansi, $4(4)$.

[13] Fajaria, A. Z., \& Isnalita. (2018). The Effect of Profitability, Liquidity, Leverage and Firm Growth of Firm Value with its Dividend Policy as a Moderating Variable. International Journal of Managerical Studies and Research (IJMSR), 6(10), 55-69.

[14] Handriani, E., \& Robiyanto. (2018). Corporate Finance and Firm Value in The Indonesian Manufacturing Companies. International Research Journal of Business Studies, 11(2), 113-127. 
[15] Hapsoro, D., \& Falih, Z. N. (2020). The Effect of Firm Size, Profitability, and Liquidity on The Firm Value Moderated by Carbon Emission Disclosure. Journal of Accounting and Investment, 21(2).

[16] Harford, J. (1999). Corporate Cash Reserves and Acquisitions. The Journal of Finance, 54(6), 1969-1997.

[17] Harun, M. S., Hussainey, K., Mohd Kharuddin, K. A., \& Farooque, O. Al. (2020). CSR Disclosure, Corporate Governance and Firm Value: a study on GCC Islamic Banks. International Journal of Accounting and Information Management, 28(4), 607-638.

[18] Hasibuan, V., Dzulkirom, M., \& Endang, N. G. W. (2016). Pengaruh Leverage dan Profitabilitas terhadap Nilai Perusahaan (Studi pada Perusahaan Property dan Real Estate yang Terdaftar di Bursa Efek Indonesia Periode Tahun 2012-2015). Jurnal Administrasi Bisnis (JAB), 39(1), 139-147.

[19] Hulu, S., \& Caniago, F. (2019). Pengaruh Sales Growth, Debt Policy dan Corporate Risk terhadap Nilai Perusahaan pada Perusahaan Property dan Real Estate yang Terdaftar di Bursa Efek Indonesia Tahun 2013-2016. Jesya (Jurnal Ekonomi \& Ekonomi Syariah), 2(2), 273-285.

[20] Ilhamsyah, F. L., \& Soekotjo, H. (2017). Pengaruh Kebijakan Dividen, Keputusan Investasi, dan Profitabilitas terhadap Nilai Perusahaan. Jurnal Ilmu Dan Riset Manajemen, 6(2), 1-15.

[21] Isnawati, F. N., \& Widjajanti, K. (2019). Pengaruh Kepemilikan Institusional, Profitabilitas, Ukuran Perusahaan dan Pertumbuhan Penjualan terhadap Nilai Perusahaan dengan Struktur Modal Sebagai Variabel Intervening. Jurnal Riset Ekonomi Dan Bisnis, 12(1), 71.

[22] Jannatun, A., \& Chomsatu, Y. (2019). Pengaruh Profitabilitas, Kebijakan Hutang, Degree of Operating Leverage terhadap Nilai Perusahaan. JAD: Jurnal Riset Akuntansi Dan Keuangan Dewantara, 2(1), 45-52.

[23] Jensen, M. C., \& Meckling, W. H. (1976). Theory of The Firm: Managerial Behavior, Agency Costs and Ownership Structure. Journal of Financial Economics, 3, 305-360.

[24] Kanta, A. G. A., \& Surasni, N. K. (2021). The Effect of Leverage and Profitability on Firm Value with Dividend Policy as Moderation Variable ( Studies in Manufacturing Companies for the 2014-2018 Period ). International Journal of Multicultural and Multireligious Understanding, 8(1), 245-255.

[25] Kumalasari, D., \& Riduwan, A. (2018). Pengaruh Keputusan Investasi, Keputusan Pendanaan dan Kebijakan Dividen terhadap Nilai Perusahaan. Jurnal Ilmu Dan Riset Akuntansi, 7(1).

[26] Khoeriyah, A. (2020). Pengaruh Size, Leverage, Sales Growth dan IOS terhadap Nilai Perusahaan. Profita: Komunikasi Ilmiah Akuntansi Dan Perpajakan, 134 13(1), 58-72.

[27] Lathifah, H. M., Febrianti, D. S., Utami, A. P., Ulhaq, A. A., Tulasmi, T., \& Mukti, T. (2021). Dampak Pandemi Covid-19 Terhadap Nilai Harga Saham Syariah di Indonesia. Jurnal Ilmiah Ekonomi Islam, 7(1), 223-229.

[28] Lumoly, S., Murni, S., \& Untu, V. N. (2018). Pengaruh Likuiditas, Ukuran 
Perusahaan dan Profitabilitas terhadap Nilai Perusahaan (Studi pada Perusahaan Logam dan Sejenisnya yang Terdaftar di Bursa Efek Indonesia). Jurnal EMBA: Jurnal Riset Ekonomi, Manajemen, Bisnis Dan Akuntansi, 6(3), 1108-1117.

[29] Mandalika, A. (2016). Pengaruh Struktur Aktiva, Struktur Modal, dan Pertumbuhan Perusahaan pada Perusahaan Publik yang Terdaftar di Bursa Efek Indonesia. Jurnal Berkala Ilmiah Efisiensi, 16(01), 207-218.

[30] Marceline, L., \& Harsono, A. (2017). Pengaruh Good Corporate Governance, Karakteristik Perusahaan, Likuiditas, Leverage, Kebijakan Dividen, dengan Nilai Perusahaan. Jurnal Bisnis Dan Akuntansi, 19(1a), 226-236.

[31] Marini, Y., \& Marina, N. (2017). Pengaruh Good Corporate Governance terhadap Nilai Perusahaan. Jurnal Humaniora, 1(1), 7-20.

[32] McMullen, D. A., and Raghunandan, K. 1996. Enhancing Audit Committee Effectiveness. Journal of Accountancy, 18(2), 79-81.

[33] Musabbihan, N. A., \& Purnawati, N. K. (2018). Pengaruh Profitabilitas dan Kebijakan Dividen terhadap Nilai Perusahaan dengan Struktur Modal sebagai Pemediasi. E-Jurnal Manajemen Universitas Udayana, 7(4), 1979- 2009.

[34] Nelwan, A., \& Tulung, J. E. (2018). Pengaruh Kebijakan Dividen, Keputusan Pendanaan, dan Keputusan Investasi terhadap Nilai Perusahaan Pada Saham Bluechip yang Terdaftar di BEI. Jurnal EMBA: Jurnal Riset Ekonomi, Manajemen, Bisnis Dan Akuntansi, 6(4), 2878-2887.

[35] Ningtyas, K. L., Suhadak, \& Nuzula, N. F. (2014). Pengaruh Good Corporate Governance terhadap Nilai Perusahaan (Studi Pada Perusahaan yang Terdaftar di Jakarta Islamic Index Tahun 2010-2013 ). Jurnal Administrasi Bisnis (JAB), 17(1), 1-9.

[35] Oktaryani, G. A. S., Nugraha, I. N., Sofiyah, S., Negara, I. K., \& Mandra, I. G. (2017). Pengaruh Good Corporate Governance terhadap Nilai Perusahaan dengan Profitabilitas sebagai Variabel Intervening (Studi Pada Perusahaan Perbankan di Bursa Efek Indonesia). Jurnal Distribusi: Jurnal Ilmu Manajemen Dan Bisnis, 5(2), 45-58.

[36] Oktaviani, M., Rosmaniar, A., \& Hadi, S. (2019). Pengaruh Ukuran Perusahaan (Size) dan Struktur Modal terhadap Nilai Perusahaan. Jurnal Balance, 16(1).

[37] Oktaviarni, F., Murni, Y., \& Suprayitno, B. (2018). Pengaruh Profitabilitas, Likuiditas, Leverage, Kebijakan Dividen, dan Ukuran Perusahaan terhadap Nilai Perusahaan ( Studi Empiris Perusahaan Sektor Real Estate, Properti, dan Konstruksi Bangunan yang Terdaftar di Bursa Efek Indonesia Tahun 20142016). Jurnal Akuntansi Universitas Jember, 16(2).

[38] Prasetyorini, B. F. (2013). Pengaruh Ukuran Perusahaan, Leverage, Price Earning Ratio, dan Profitabilitas terhadap Nilai Perusahaan. Jurnal Ilmu Manajemen, 1(1).

[39] Pratama, I. G. B. A., \& Wiksuana, I. G. B. (2016). Pengaruh Ukuran Perusahaan dan Leverage terhadap Nilai Perusahaan dengan Profitabilitas sebagai Variabel Mediasi. E-Jurnal Manajemen Universitas Udayana, 5(2), 1338- 1367.

[40] Puja Wijaya, I., \& Purnawati, N. (2014). Pengaruh Likuiditas Dan Kepemilikan 
Institusional terhadap Nilai Perusahaan Dimoderasi Oleh Kebijakan Dividen. EJurnal Manajemen Universitas Udayana, 3(12).

[41] Purbopangestu, H. W., \& Subowo. (2014). Pengaruh Good Corporate Governance terhadap Nilai Perusahaan dengan Corporate Social Responsibility sebagai Variabel Intervening. Accounting Analysis Journal, 3(3), 321-333.

[42] Ramadhanty, N. R., \& Sukmaningrum, P. S. (2020). The Effect of Return on Assets, Quick Ratio, Debt to Total Assets and Dividend Payout Ratio on the Value of Companies Listed in Jakarta Islamic Index (JII). Jurnal Ekonomi Syariah Teori Dan Terapan, 7(6), 1091-1101.

[43] Raharja, R. S. P. (2014). Analisis Pengaruh Corporate Governance terhadap Nilai Perusahaan. Dipenogoro Journal of Accounting, 3(3), 1-13.

[44] Retno, D. R., \& Prihatinah, D. (2012). Pengaruh Good Corporate Governance dan Pengungkapan Corporate Social Responsibility terhadap Nilai Perusahaan (Studi Empiris Pada Perusahaan yang Terdaftar di Bursa Efek Indonesia Periode 2007 - 2010). Jurnal Nominal, 1(1), 12-14.

[45] Ross, S. A. (1977). The Determination of Financial Structure: The IncentiveSignalling Approach. The Bell Journal of Economics, 8(1), 23-40.

[46] Rudangga, I. G. N. G., \& Sudiarta, G. M. (2016). Pengaruh Ukuran Perusahaan, Leverage, dan Profitabilitas terhadap Nilai Perusahaan. E-Jurnal Manajemen Universitas Udayana, 5(7), 4394-4422.

[47] Santoso, B. A., \& Budiarti, A. (2020). Profitabilitas Sebagai Mediasi Pertumbuhan Penjualan dan Struktur Modal terhadap Nilai Perusahaan. JESYA Uurnal Ekonomi \& Ekonomi Syariah), 3(2), 45-57.

[48] Santoso, S. (2015). Menguasai Statistik Parametrik: Konsep dan Aplikasi dengan SPSS. PT. Elex Media Komputindo.

[49] Sarafina, S., \& Saifi, M. (2017). Pengaruh Good Corporate Governance terhadap Kinerja Keuangan dan Nilai Perusahaan (Studi pada Badan Usaha Milik Negara (BUMN) yang Terdaftar di Bursa Efek Indonesia Periode 2012-2015). Jurnal Administrasi Bisnis (JAB), 50(3), 108-117.

[50] Soerzawa, D., Yusmaniarti, \& Suhendra, C. (2018). Pengaruh Penghindaran Pajak terhadap Nilai Perusahaan dengan Leverage sebagai Variabel Moderasi. BILANCIA: Jurnal Ilmiah Akuntansi, 2(4), 367-377.

[51] Suardikha, I. M. S., \& Muryati, N. N. T. S. (2014). Pengaruh Corporate Governance Pada Nilai Perusahaan. E-Jurnal Akuntansi Universitas Udayana, 9(2), 411-429.

[52] Sudiani, N., \& Darmayanti, N. (2016). Pengaruh Profitabilitas, Likuiditas, Pertumbuhan, Dan Investment Opportunity Set terhadap Nilai Perusahaan. EJurnal Manajemen Unud, 5(7), 4545-4547.

[53] Sunardi, N. (2019). Mekanisme Good Corporate Governance terhadap Nilai Perusahaan Dengan Leverage Sebagai Variabel Intervening Pada Perusahaan Manufaktur yang Terdaftar di Bursa Efek Indonesia Tahun 2012-2018. JIMF (Jurnal Ilmiah Manajemen Forkamma), 2(3), 48-61.

[54] Sutama, D. R., \& Lisa, E. (2018). Pengaruh Leverage dan Profitabilitas terhadap Nilai Perusahaan (Studi Pada Perusahaan Sektor Manufaktur Food and Beverage yang terdaftar di Bursa Efek Indonesia. Jurnal Sains Manajemen Dan 
Akuntansi, 10(1), 21-39.

[55] Syafitri, T., Nuzula, N. F., \& Nurlaily, F. (2018). Pengaruh Good Corporate Governance terhadap Nilai Perusahaan (Studi pada Perusahaan Industri Sub Sektor Logam dan Sejenisnya yang Terdaftar di BEI Periode 2012-2016). Jurnal Administrasi Bisnis (JAB), 56(1), 118-126.

[56] Ukhriyawati, C. F., \& Dewi, R. (2019). Pengaruh Struktur Modal, Pertumbuhan Perusahaan, dan Ukuran Perusahaan terhadap Nilai Perusahaan Pada Perusahaan LQ-45 yang Terdaftar di Bursa Efek Indonesia. Jurnal Equilibiria, 6(1), 1-14.

[57] Umam, A. C., \& Hartono, U. (2019). Firm Size, Profitabilitas, Struktur Modal, Kebijakan Dividen, GCG, CSR, dan Nilai Perusahaan (Studi Pada Perusahaan Sektor Finance di Bursa Efek Indonesia). Jurnal Ilmu Manajemen, 7(3), 642-654.

[58] Wardoyo, \& Veronica, T. M. (2013). Pengaruh Good Corporate Governance, Corporate Social Responsibility, dan Kinerja Keuangan terhadap Nilai Perusahaan. Jurnal Dinamika Manajemen, 4(2), 132-149.

[59] Wiguna, R. A., \& Yusuf, M. (2019). Pengaruh Profitabilitas dan Good Corporate Governance terhadap Nilai Perusahaan (Studi Empiris pada Perusahaan yang Terdaftar di Bursa Efek Indonesia). ECONBANK: Journal of Economics and Banking, 1(2), 158-173.

[60] Yusmaniarti, Setorini, H., \& Pitaloka, L. (2019). Influence of Good Corporate Governance, Profitability, and Leverage Towards Companies Value at Indonesian Property and Real Estate Companies. Bilancia: Jurnal Ilmiah Akuntansi, 3(4), 406-418. 